Article

\title{
Human Beta Defensin 2 Selectively Inhibits HIV-1 in Highly Permissive CCR6 ${ }^{+} \mathrm{CD}^{+}{ }^{+} \mathrm{T}$ Cells
}

\author{
Mark K. Lafferty ${ }^{1,2}$, Lingling Sun ${ }^{1}$, Aaron Christensen-Quick ${ }^{1,2}$, Wuyuan Lu ${ }^{1,3}$ and \\ Alfredo Garzino-Demo 1,2,4,* \\ 1 Division of Basic Science, Institute of Human Virology, University of Maryland School of Medicine, \\ Baltimore, MD 21201, USA; mark.lafferty@umaryland.edu (M.K.L.); lsun@ihv.umaryland.edu (L.S.); \\ aac027@ucsd.edu (A.C.-Q.); wlu@ihv.umaryland.edu (W.L.) \\ 2 Department of Microbiology and Immunology, University of Maryland School of Medicine, \\ Baltimore, MD 21201, USA \\ 3 Department of Biochemistry, University of Maryland School of Medicine, Baltimore, MD 21201, USA \\ 4 Department of Molecular Medicine, University of Padova, Padova 35121, Italy \\ * Correspondence: agarzinodemo@ihv.umaryland.edu; Tel.: +1-41-0706-4689 \\ Academic Editor: Theresa Chang \\ Received: 14 March 2017; Accepted: 10 May 2017; Published: 16 May 2017
}

\begin{abstract}
Chemokine receptor type $6(\mathrm{CCR} 6)^{+} \mathrm{CD} 4^{+} \mathrm{T}$ cells are preferentially infected and depleted during HIV disease progression, but are preserved in non-progressors. CCR6 is expressed on a heterogeneous population of memory $\mathrm{CD}^{+} \mathrm{T}$ cells that are critical to mucosal immunity. Preferential infection of these cells is associated, in part, with high surface expression of CCR5, CXCR4, and $\alpha 4 \beta 7$. In addition, $\mathrm{CCR} 6^{+} \mathrm{CD}^{+}{ }^{+} \mathrm{T}$ cells harbor elevated levels of integrated viral DNA and high levels of proliferation markers. We have previously shown that the CCR6 ligands MIP- $3 \alpha$ and human beta defensins inhibit HIV replication. The inhibition required CCR6 and the induction of APOBEC3G. Here, we further characterize the induction of apolipoprotein B mRNA editing enzyme (APOBEC3G) by human beta defensin 2 . Human beta defensin 2 rapidly induces transcriptional induction of APOBEC3G that involves extracellular signal-regulated kinases 1/2 (ERK1/2) activation and the transcription factors NFATc2, NFATc1, and IRF4. We demonstrate that human beta defensin 2 selectively protects primary $\mathrm{CCR} 6^{+} \mathrm{CD}^{+}{ }^{+} \mathrm{T}$ cells infected with HIV-1. The selective protection of $\mathrm{CCR}^{+} \mathrm{CD}^{+} \mathrm{T}$ cell subsets may be critical in maintaining mucosal immune function and preventing disease progression.
\end{abstract}

Keywords: defensins; viruses; immune response; HIV; CCR6; pathogenesis; human beta defensin 2; Th17

\section{Introduction}

HIV preferentially infects and depletes chemokine receptor type $6(\mathrm{CCR} 6)^{+} \mathrm{CD} 4^{+} \mathrm{T}$ cells despite suppressive antiretroviral therapy [1,2]. The chemokine receptor CCR6 is critical for mucosal immunity [3-9]. CCR6 is a marker of memory $\mathrm{CD}^{+} \mathrm{T}$ cells that express the HIV co-receptors, CCR5 and CXC chemokine receptors type 4 (CXCR4), and the integrin $\alpha 4 \beta 7[2,10]$. In addition, CCR6 is a marker of Th17 cells which express CXCR4 and often express CCR5 [11-13]. Th17 cells and the $\mathrm{CCR}^{+} \mathrm{CCR} 4^{+} \mathrm{CD} 4^{+} \mathrm{T}$ cell subset, which are enriched for interleukin 17 (IL-17), produce lower levels of the CCR5 ligands CCL3, CCL4, and CCL5 [2,13]. The high proportion and increased expression of CCR5 and $\alpha 4 \beta 7$ enhances entry and HIV envelope binding to CCR6 ${ }^{+} \mathrm{CD} 4^{+} \mathrm{T}$ cells $[2,13,14]$. Further, lower expression of CCR5 ligands by $\mathrm{CCR} 6^{+} \mathrm{CD} 4^{+} \mathrm{T}$ cells reduces self-protection and increases susceptibility $[14,15]$. In addition to increased susceptibility, $\mathrm{CCR} 6^{+} \mathrm{CD} 4^{+} \mathrm{T}$ cells are more permissive to HIV-1 [16]. Independent of entry, memory $\mathrm{CCR} 6^{+} \mathrm{CD} 4^{+} \mathrm{T}$ cells have higher levels of replication when infected with single-cycle VSVG-GFP pseudotyped HIV which was further enhanced only in 
$\mathrm{CCR}^{+}$cells treated with retinoic acid [17]. $\mathrm{CCR} 6^{+} \mathrm{CD} 4^{+} \mathrm{T}$ cells, upon HIV infection are prone to apoptosis, which may contribute to their preferential depletion $[1,2,13,14,17]$. However, some subsets of CCR6 $6^{+}$cells may contribute to the persistent HIV reservoir [18-20].

The gut associated lymphoid tissue (GALT) is enriched in $\mathrm{CCR} 6^{+} \mathrm{CD} 4^{+} \mathrm{T}$ cells including Th17 cells which are preferentially depleted in HIV-1 infection and pathogenic simian immunodeficiency virus (SIV) infection of rhesus macaques, starting during acute infection [21-24]. The severe depletion of GALT Th17 cells is not restored despite uninterrupted and suppressive highly active antiretroviral therapy which results in defects in mucosal immunity and barrier function that can lead to impaired bacterial control and bacterial dissemination [25-29]. In contrast, gut Th17 cells in HIV-1-infected long-term non-progressors are preserved and gut Th17 cells in non-pathogenic SIV infection are depleted but subsequently restored, and these animals do not develop AIDS or chronic immune activation $[21,28,30]$. These findings suggest that preservation of mucosal Th17 cells is critical to controlling microbial infections and maintaining intestinal barrier function, which may prevent microbial translocation and immune activation [21,28,31].

IL-17 producing cells are an important component of mucosal immune defenses against extracellular and intracellular bacteria and fungi, many of which are opportunistic infections observed in AIDS patients [32-35]. IL-17 plays an essential role in epithelial and mucosal defenses through the induction of pro-inflammatory cytokines, chemokines, factors involved in wound repair and enterocyte homeostasis, and is a potent inducer of human beta defensin 2 (hBD2) [36-43]. In addition, Th17 cells produce IL-22, which stimulates the production of hBD2 by epithelial cells [44,45]. Defensins are expressed at mucosal sites and exhibit broad antimicrobial activity against Gram-positive and Gram-negative bacteria, mycobacteria, fungi, enveloped viruses, and non-enveloped viruses [46-57]. In addition to direct antimicrobial properties, beta defensins recruit innate and adaptive effector cells to sites of inflammation, induce cytokines and mast cell degranulation, and aid in wound healing [58-68]. We and others have previously shown reduced infectivity of HIV-1 virions treated with hBDs [69,70]. We have also reported that hBD2 inhibits HIV-1 post-entry requiring the upregulation of the host restriction factor apolipoprotein B mRNA editing enzyme (APOBEC3G) [71]. APOBEC3G inhibits HIV replication involving deamination and deamination independent mechanisms and is associated with HIV control in vivo [72-78]. The hBD2-mediated increase in APOBEC3G depended on the expression of CCR6, the receptor used by hBD2 to induce chemotaxis of memory T cells [58,71]. We sought to identify the signaling pathway(s) that resulted in the upregulation of APOBEC3G in CCR6 ${ }^{+}$cells given their importance to mucosal immunity. Here, we report that hBD2 induced APOBEC3G transcripts via extracellular signal-regulated kinases $1 / 2(E R K 1 / 2)$ activation in concomitance with increased binding of transcription factors NFATc2, NFATc1, and IRF-4 on the APOBEC3G promoter. Further, hBD2 selectively inhibited HIV-1 replication in CCR6 $6^{+} \mathrm{CD} 4^{+} \mathrm{T}$ cells, suggesting CCR6 as a target for preventive and therapeutic approaches against HIV.

\section{Materials and Methods}

\subsection{Isolation and Culture of Primary Cells and Cell Lines}

Human peripheral blood mononuclear cells (PBMCs) were isolated from leukapheresis-processed blood (NY Blood Center, New York, NY, USA) using Lymphoprep ${ }^{\mathrm{TM}}$. CD4 $4^{+}$T cells (purity of $>95 \%$ as determined by flow cytometry) were isolated from unstimulated PBMCs using the Human $\mathrm{CD}^{+}{ }^{+} \mathrm{T}$ Cell Enrichment Kit (Stem Cell Technologies Inc., Vancouver, BC, Canada). CCR6 ${ }^{+} \mathrm{CD} 4^{+} \mathrm{T}$ cells were isolated from unstimulated $\mathrm{CD}^{+} \mathrm{T}$ cells using a CCR6-APC antibody (BD Biosciences, San Jose, CA, USA) and BD FACSAria II (BD Biosciences) performed at the Institute of Human Virology Flow cytometry core. PBMCs, $\mathrm{CD} 4^{+} \mathrm{T}$ cells, $\mathrm{CCR} 6^{+} \mathrm{CD} 4^{+} \mathrm{T}$ cells, and $\mathrm{CCR} 6{ }^{-} \mathrm{CD} 4^{+} \mathrm{T}$ cells were maintained in complete RPMI-1640 media. Cells were activated with $10 \mathrm{ng} / \mathrm{mL}$ IL-2 and $2.5 \mu \mathrm{g} / \mathrm{mL}$ phytohemagglutinin (PHA) or with $5 \mu \mathrm{g} / \mathrm{mL}$ anti-CD3 coated plates and $1 \mu \mathrm{g} / \mathrm{mLanti-CD} 28$ (eBioscience, San Diego, CA, USA) for $48 \mathrm{~h}$ and then maintained in complete RPMI-1640 media and $10 \mathrm{ng} / \mathrm{mL}$ IL-2 at 
a density of $1 \times 10^{6}$ cells /mL. JKT-FT7 and JKT-FT7 CCR6 GFP cells, derivatives of the Jurkat CD4 ${ }^{+}$T lymphoblastoid cell line, were maintained in complete RPMI-1640 media. The JKT-FT7 and JKT-FT7 CCR6 GFP cell lines were a gift from Dr. Sam Hwang.

\subsection{Flow Cytometry}

Cells were surface stained with fluorochrome conjugated antibodies and isotype matched anti-IgG controls for $20 \mathrm{~min}$. Stained cells were acquired on a FACSAria II (BD Biosciences) with a minimum of 10,000 gated events. Lymphocytes were gated based upon live/dead staining and forward and side scatter profiles. Gated populations were analyzed using FlowJo software (Tree Star, Inc., St. Ashland, OR, USA). FITC- or PE-anti-CD4, APC-or PE-anti-CCR6 were purchased from BD Biosciences.

\subsection{Virus Production}

HIV-1 $\mathrm{BaL}$ (R5 tropic) was prepared from monocyte-derived macrophages in RPMI-1640 media/human AB serum. Pseudotyped virions were generated by calcium phosphate cotransfection of 293T cells with an HIV-1 reporter virus, pNL4-3-deltaE-enhanced green fluorescent protein (EGFP) (the following reagent was obtained through the NIH AIDS Reagent Program, Division of AIDS, NIAID, NIH: pNL4-3-deltaE-EGFP (Cat\# 11,100) from Drs. Haili Zhang, Yan Zhou, and Robert Siliciano) and an amphotropic murine leukemia virus (AMLV) envelope expressing plasmid.

\subsection{Infectivity Assays}

Activated PBMC, $\mathrm{CCR}^{+} \mathrm{CD}^{+} \mathrm{T}$ cells and $\mathrm{CCR} 6^{-} \mathrm{CD} 4^{+} \mathrm{T}$ cells $\left(10^{5}\right.$ cells $/$ well $)$ were infected for $2 \mathrm{~h}$ with 100 TCID50 of HIV-1 $1_{\mathrm{BaL}}$, or AMLV pNL4-3 $\triangle \mathrm{E}-\mathrm{EGFP}$. After $2 \mathrm{~h}$, cells were washed with phosphate-buffered saline (PBS, Arlington, TX, USA), and complete media was added with the appropriate treatment. Infection was monitored by p24 enzyme-linked immunoabsorbent assay (ELISA) with the use of a commercially available kit (PerkinElmer Life and Analytical Sciences, Boston, MA, USA) or by flow cytometry for GFP.

\subsection{Immunoblotting}

Cells were lysed with Radioimmunoprecipitation (RIPA) buffer (Sigma-Aldrich, Saint Louis, MO, USA) containing $1 \times$ ethylenediaminetetraacetic acid (EDTA)-free protease inhibitor cocktail (Calbiochem, Billerica, CA, USA), $0.1 \mathrm{mM}$ phenylmethane sulfonyl fluoride (PMSF), and clarified by centrifugation. Total protein concentration was determined by detergent-compatible (DC) Protein Assay (Bio-Rad, Hercules, CA, USA), and equal amounts of total protein were subjected to sodium dodecyl sulfate-polyacrylamide gel electrophoresis analysis. The primary antibodies included APOBEC3G rabbit antisera (the following reagent was obtained through the NIH AIDS Reagent Program, Division of AIDS, NIAID, NIH: anti-ApoC17 from Dr. Klaus Strebel) and mouse anti- $\beta$-actin (Abcam, Cambridge, UK).

\subsection{Quantitative RT-PCR}

Activated CD4 ${ }^{+}$T cells, JKT-FT7, and JKT-FT7 CCR6 GFP cells $\left(0.5 \times 10^{6}\right.$ cells per timepoint $)$ were untreated or pre-treated with actinomycin $\mathrm{D}(10 \mu \mathrm{g} / \mathrm{mL})$ and subsequently incubated in the presence or absence of hBD2 $(20 \mu \mathrm{g} / \mathrm{mL})$. RNA was extracted with the use of the RNeasy Kit with On-Column DNase digestion (Qiagen, Hilden, Germany) at the indicated timepoints. First-strand cDNA was synthesized from $500 \mathrm{ng}$ total RNA with the use of the iScript cDNA Synthesis Kit (Bio-Rad). cDNA was analyzed by real-time qPCR with iQSYBR green supermix (Bio-Rad) with the following primers: APOBEC3G forward 5'-CGCAGCCTGTGTCAGAAAAG-3' and reverse 5'-CCAACAGTGCTGAAATTCGTCATA-3 ${ }^{\prime}$, and 18S forward 5'-ATCAACTTTCGATGGTAGTCG-3' and reverse: $5^{\prime}$-TCCTTGGATGTGGTAGCCG-3'. $\Delta \Delta C_{\mathrm{t}}$ method was used to calculate fold change between untreated and treated cells normalized to $18 \mathrm{~S}$ ribosomal RNA [79]. 


\subsection{Fast Protein Liquid Chromatography}

Cells were lysed in ice cold lysis buffer (50 mM (4-(2-hydroxyethyl)-1-piperazineethanesulfonic acid (HEPES), pH 7.4, $125 \mathrm{mM} \mathrm{NaCl}, 0.2 \%$ NP-40, $0.1 \mathrm{mM}$ PMSF and 1× EDTA-Free protease inhibitor cocktail (Calbiochem)) and clarified by centrifugation. Total protein concentration was determined by DC Protein Assay (Bio-Rad), and equal amounts of total protein were subjected to gel filtration using a Superose 6 10/300 GL gel filtration column and AKTA Explorer (GE Healthcare, Little Chalfont, UK). Molecular weight was determined using a Gel Filtration Markers Kit for gel filtration chromatography (Sigma-Aldrich). Twenty-four $1 \mathrm{~mL}$ fractions were collected and equal volumes were subjected to sodium dodecyl sulfate-polyacrylamide gel electrophoresis (SDS-PAGE) analysis and probed with APOBEC3G rabbit antisera.

\subsection{Chromatin Immunoprecipitation (ChIP) Assays}

Chromatin was prepared according to the ChIP-IT Express Enzymatic protocol (Active Motif, Carlsbad, CA, USA). Immunoprecipitation was performed overnight using $2 \mu \mathrm{g}$ of anti-NFATc1, anti-NFATc2, anti-IRF4 (Santa Cruz Biotechnology, Dallas, TX, USA), and anti-RNA Pol II and anti-IgG (Active Motif). Following incubation with antibody, DNA was eluted according to the Active Motif protocol and DNA was purified using the QIAquick PCR purification kit (Qiagen). Real-time qPCR was performed using iQSYBR green supermix (Bio-Rad) with the following primers: APOBEC3G ChIP-F 5'-GGG GAG GGG CTT GTG C- $3^{\prime}$ and APOBEC3G ChIP-R 5'-AAG GCA ATT GCA AAG GGA A-3'. PCR was performed in triplicate with reaction conditions of $95^{\circ} \mathrm{C}$ for $10 \mathrm{~min}$ followed by 40 cycles of $95^{\circ} \mathrm{C}$ for $30 \mathrm{~s}, 6{ }^{\circ} \mathrm{C}$ for $1 \mathrm{~min}$. Fold enrichment was calculated for each ChIP antibody used as quantity of ChIP DNA divided by amount of IgG DNA.

\subsection{Total Chemical Synthesis of $h B D 2$ and MIP-3 $\alpha$}

hBD2 was chemically synthesized by solid-phase peptide synthesis with the use of a custom-modified procedure tailored from the previously published in situ neutralization protocol developed for Boc chemistry [59]. The $\beta$ connectivity of three disulfide bonds (Cys1-Cys5, Cys2-Cys4, Cys3-Cys6) in highly pure synthetic hBD2 was independently verified by mass mapping of peptide fragments generated by enzymatic digestion and Edman degradation [59]. Correct folding of synthetic macrophage Inflammatory Protein-3 (MIP-3 $\alpha$ ) was demonstrated by the solution of its high-resolution $x$-ray crystal structure. Protein concentrations were determined by absorbance measurements at $280 \mathrm{~nm}$ with the use of molar extinction coefficients.

\subsection{Statistical Analysis}

All statistical analysis were performed using GraphPad Prism software version 5 (GraphPad Software, La Jolla, CA, USA). Statistical significance between paired samples ( $p$ values $<0.05$ were considered significant) was calculated using a 2-tailed Student $t$ test.

\section{Results}

\section{1. $C C R 6^{+}$Cells Are Protected by hBD2}

$\mathrm{CCR}^{+}{ }^{+} \mathrm{CD} 4^{+} \mathrm{T}$ cells are preferentially infected by HIV-1 and depleted [1,2]. The frequency of $\mathrm{CD} 4^{+}$ $\mathrm{T}$ cells that express CCR6 varies by subtype. CCR6 is prominently expressed on peripheral blood $\mathrm{CD}_{5} \mathrm{RO}^{+}, \mathrm{CCR}^{+}$, and IL-17 producing CD4 ${ }^{+} \mathrm{T}$ cells [10-12]. PBMC and peripheral blood CD4 ${ }^{+} \mathrm{T}$ cells were isolated and infected, as described in Section 2 (Materials and Methods). Consistent with reported findings, $\mathrm{CCR}^{+} \mathrm{PBMC}$ and $\mathrm{CCR} 6^{+} \mathrm{CD} 4^{+} \mathrm{T}$ cells have higher levels of viral replication compared to $\mathrm{CCR6}^{-}$cells when infected with single-cycle AMLV pseudotyped virions, which suggests the enhanced replication in $\mathrm{CCR}^{+}$cells is independent of co-receptor expression (Figure 1a). We previously reported that the CCR6 ligand hBD2 inhibits HIV-1 directly and by a post-entry mechanism during reverse 
transcription $[70,71]$. Using CCR6 ${ }^{+}$and CCR6 ${ }^{-}$Jurkat-derived cell lines, we showed that the post-entry inhibition required the expression of CCR6 [71]. To evaluate the requirement of CCR6 for inhibition in primary cells, peripheral blood $\mathrm{CD} 4^{+} \mathrm{T}$ cells were isolated, separated into CCR6 positive and negative fractions, and activated with anti-CD3 and anti-CD28. Cells were treated with $20 \mu \mathrm{g} / \mathrm{mL}$ of hBD2 for $4 \mathrm{~h}$ and subsequently washed three times with PBS to remove the hBD2 and infected with HIV- $1_{\mathrm{BaL}}$. We observed inhibition in the $\mathrm{CCR}^{+} \mathrm{CD}^{+} \mathrm{T}$ cells but not in the $\mathrm{CCR}^{-} \mathrm{CD}^{+} \mathrm{T}$ cells (Figure $1 \mathrm{~b}$ ).

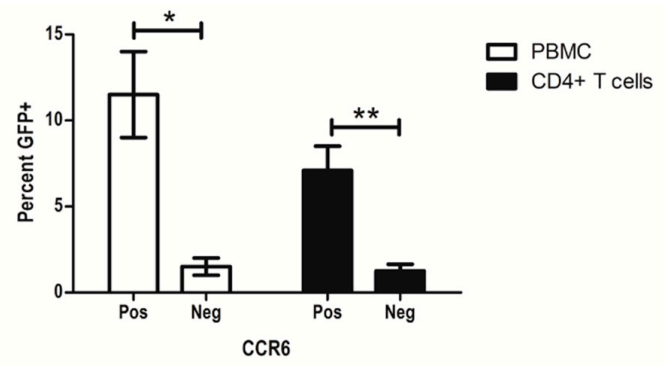

(a)
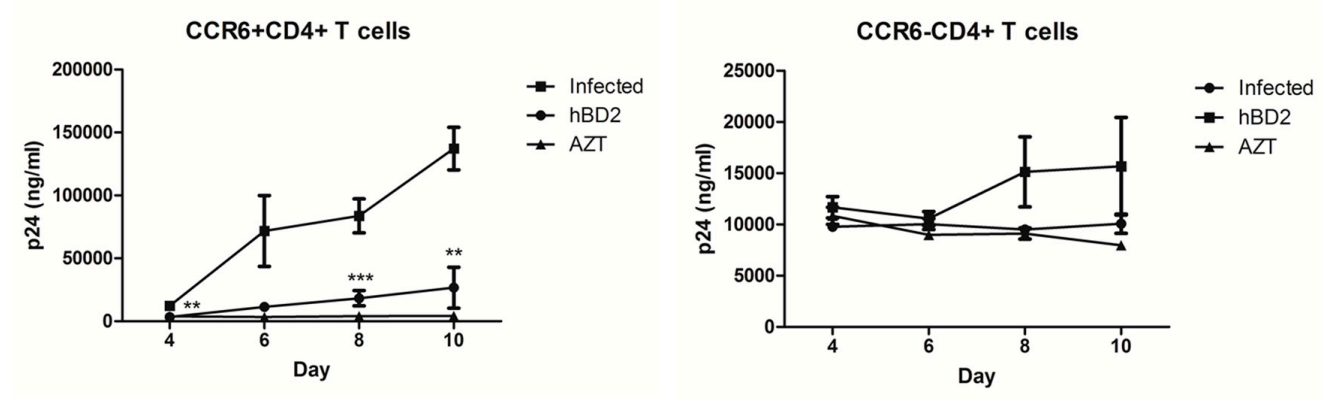

(b)

Figure 1. $\mathrm{CCR}^{+} \mathrm{CD} 4^{+} \mathrm{T}$ cells are more permissive to HIV than $\mathrm{CCR} 6^{-} \mathrm{CD} 4^{+} \mathrm{T}$ cells. (a) Peripheral blood mononuclear cells (PBMC) and $\mathrm{CD} 4^{+} \mathrm{T}$ cells were infected with amphotropic murine leukemia virus (AMLV) pseudotyped pNL4-3 $\triangle E$-EGFP virus for 3 days. Percent $\mathrm{GFP}^{+} \mathrm{CD} 4^{+} \mathrm{CD}^{+}$cells are shown for $\mathrm{CCR}^{+}$and $\mathrm{CCR} 6^{-}$cells of four independent experiments ( \pm standard error of the mean (SEM)). (b) $\mathrm{CCR}^{+}$and $\mathrm{CCR}^{-}{ }^{-} \mathrm{CD} 4^{+} \mathrm{T}$ cells were treated for $4 \mathrm{~h}$ with $20 \mu \mathrm{g} / \mathrm{mL}$ human beta-defensin 2 (hBD2), washed, and infected with 100 TCID50 of HIV-1 $1_{\mathrm{BaL}}$, corresponding to 1-2 ng of input p24. Some cells were treated after infection with $2.67 \mu \mathrm{g} / \mathrm{mL}$ of azidothymidine (AZT), for the duration of the experiment. After 6 days, HIV p24 in tissue culture supernatant was quantified by ELISA. Shown here are mean p24 ng/mL and percent inhibition $( \pm$ SEM) of three independent experiments performed in triplicate. Statistical analysis was performed by paired 2-tail Student $\mathrm{t}$ test. ${ }^{*} p<0.05$, ** $p<0.01,{ }^{* * *} p<0.001$.

\section{2. $h B D 2$ Enhances LMM and HMM APOBEC3G Expression}

Our previously published data showed that the post-entry inhibition occurred at an early stage of infection and required induction of the host restriction factor APOBEC3G [71]. We next investigated which form of APOBEC3G was present after treatment with hBD2. APOBEC3G exists in a range of molecular weight forms from a low-molecular-mass (LMM) form that restricts HIV-1 to a high molecular mass (HMM) form [80-83]. The form of APOBEC3G induced by hBD2 was determined using size exclusion chromatography. As expected, LMM APOBEC3G predominates in unstimulated $\mathrm{CD}^{+} \mathrm{T}$ cells while HMM APOBEC3G predominates in PHA stimulated CD4 ${ }^{+} \mathrm{T}$ cells $[83,84]$. Both the LMM and HMM forms of APOBEC3G exist in CD4 ${ }^{+} \mathrm{T}$ cells treated with $\mathrm{hBD} 2(20 \mu \mathrm{g} / \mathrm{mL})$ for $8 \mathrm{~h}$ that were previously stimulated with PHA (Figure 2a). In JKT-FT7 CCR6 GFP cells, the predominant form was the HMM, but after treatment with hBD2 $(20 \mu \mathrm{g} / \mathrm{mL})$, APOBEC3G was detected only in the LMM form (Figure 2b). 


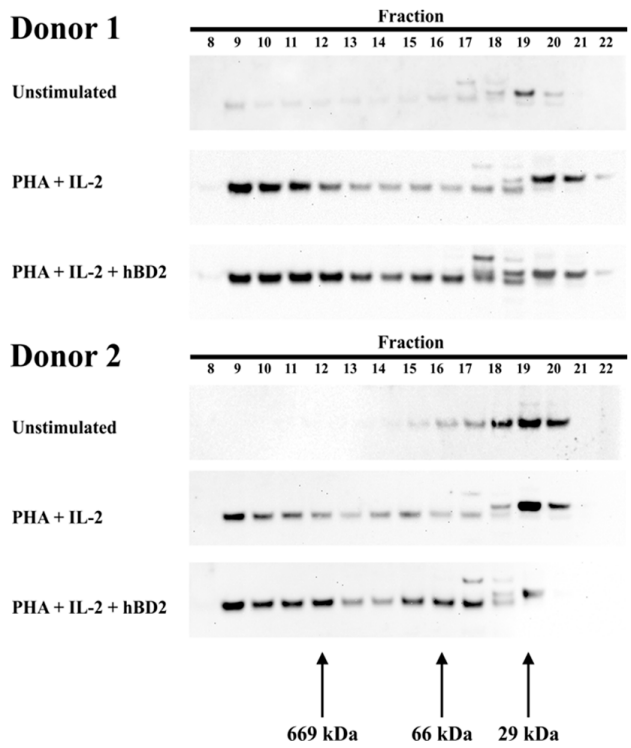

(a)

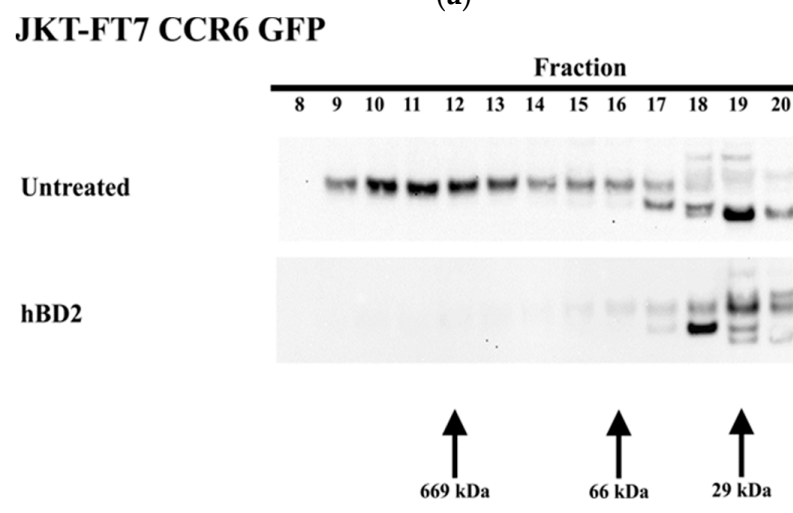

(b)

Figure 2. Induction of low-molecular-mass (LMM) and high-molecular-mass (HMM) APOBEC3G. (a) Unstimulated $\mathrm{CD}^{+}{ }^{+} \mathrm{T}$ cells or $\mathrm{CD}^{+}{ }^{+} \mathrm{T}$ cells activated with phytohemagglutinin (PHA) $(2.5 \mu \mathrm{g} / \mathrm{mL})$ and IL-2 $(10 \mathrm{ng} / \mathrm{mL})$ for $48 \mathrm{~h}$ and treated with hBD2 $(20 \mu \mathrm{g} / \mathrm{mL})$ for $8 \mathrm{~h}$. (b) JKT-FT7 CCR6 GFP cells treated with hBD2 $(20 \mu \mathrm{g} / \mathrm{mL})$ for $8 \mathrm{~h}$. Cell lysates were loaded on a gel size-exclusion column for fast protein liquid chromatography (FPLC) analysis. Twenty-four 1-mL fractions were collected. Eluted fractions were subjected to sodium dodecyl sulfate polyacrylamide gel electrophoresis (SDS-PAGE), followed by an immunoblotting assay with anti-apolipoprotein B mRNA editing enzyme (APOBEC3G) antibody.

\subsection{Induction of APOBEC3G by $h B D 2$ Requires ERK1/2 Phosphorylation}

Mitogen induction of APOBEC3G expression requires ERK1/2 activation [85,86]. To assess whether hBD2 induction of APOBEC3G involves signaling through the mitogen-activated protein kinases (MAPK) pathway, we treated activated PBMC and CD4 ${ }^{+}$T cells, JKT-FT7 CCR6 GFP cells, and JKT-FT7 cells, which are CCR6 ${ }^{-}$, with hBD2 $(20 \mu \mathrm{g} / \mathrm{mL})$ and measured phosphorylated and total ERK1/ 2 by Western blot. Treatment with $\mathrm{hBD} 2$ increased the amount of phosphorylated ERK1/2 in PBMC, CD4 ${ }^{+} \mathrm{T}$ cells, and the JKT-FT7 CCR6 GFP cells (Figure 3a). Treatment with MIP-3 $\alpha$, the cognate ligand for CCR6, activated ERK1/2 in PBMC, CD4 ${ }^{+} \mathrm{T}$ cells, and JKT-FT7 CCR6 GFP cells (Figure $3 b$ ) which further supports that signaling through CCR6 activates the ERK1/2 MAPK pathway. We next determined whether signaling through CCR6 activates the ERK1/2 pathway in primary CD4 ${ }^{+}$ $\mathrm{T}$ cells. Both hBD2 and MIP3 $\alpha$ increased the phosphorylation in primary $\mathrm{CCR} 6^{+} \mathrm{CD} 4^{+} \mathrm{T}$ cells but not in the $\mathrm{CCR} 6^{-} \mathrm{CD} 4^{+} \mathrm{T}$ cells (Figure 3c). We then tested whether the activation of ERK1/2 by hBD2 is 
required for APOBEC3G induction. $\mathrm{CD}^{+} \mathrm{T}$ cells were pre-treated with $\mathrm{U} 0126$, a specific inhibitor of MEK1/2 activation; the only known downstream substrate of phosphorylated MEK1/2 is ERK1/2 [87]. By comparing CD4 ${ }^{+}$T cells and JKT-FT7 CCR6 GFP cells (Figure 3a) with U0126 pre-treated cells, we find that pre-treatment with U0126 inhibited hBD2-mediated phosphorylation of ERK1/2 in both $\mathrm{CD}^{+}{ }^{+} \mathrm{T}$ cells and JKT-FT7 CCR6 GFP cells (Figure 3d) and induction of APOBEC3G in activated CD4 ${ }^{+}$ $\mathrm{T}$ cells (Figure $3 \mathrm{e}$ ).

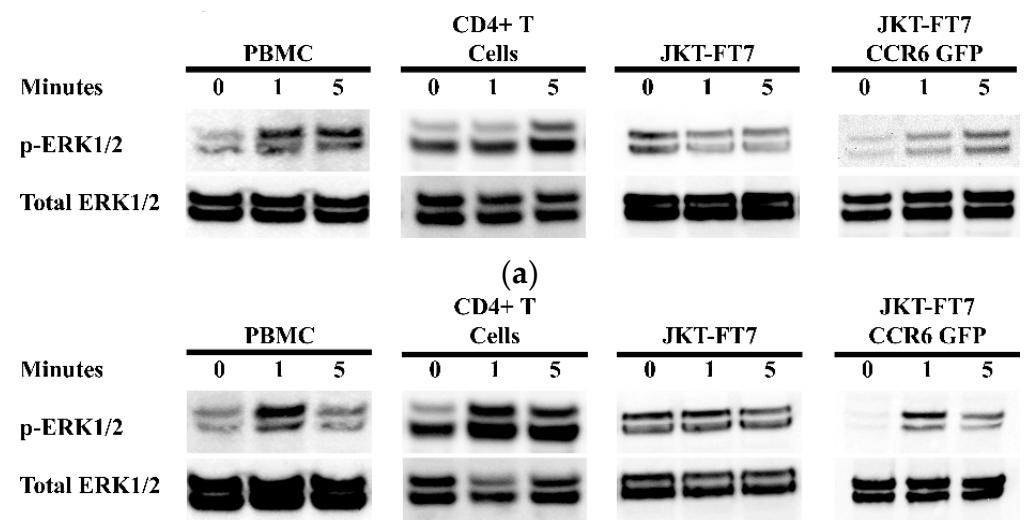

(b)
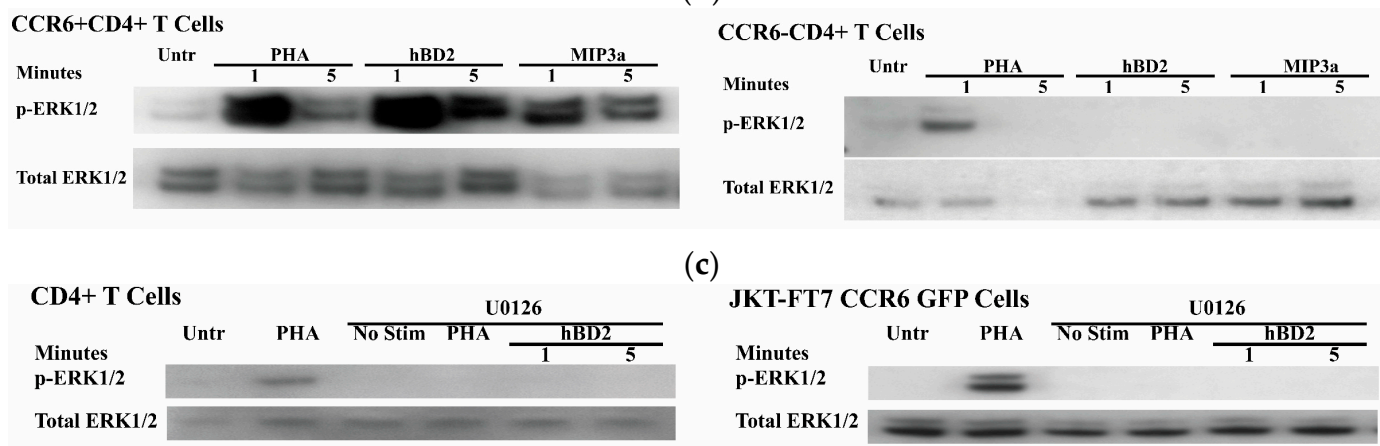

(c)
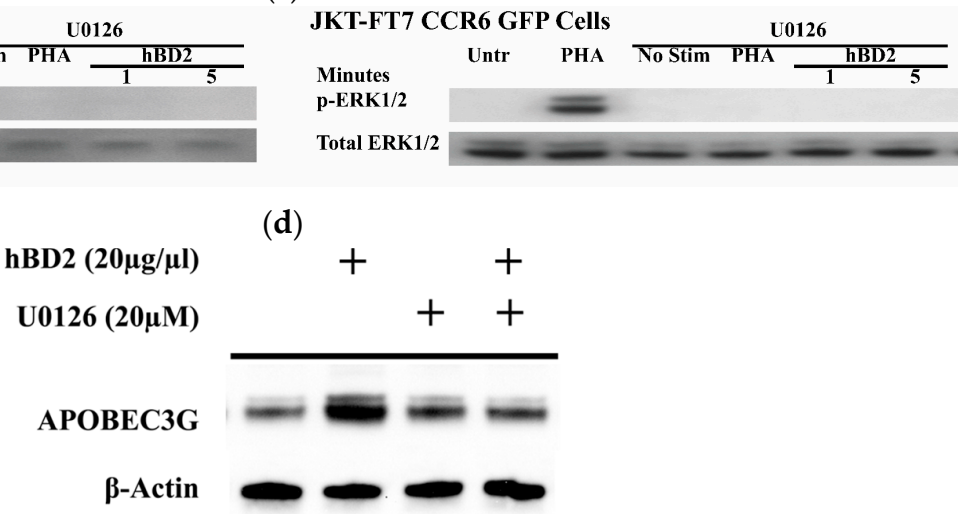

(e)

Figure 3. CCR6 ligands activate the extracellular signal-regulated kinases $1 / 2$ (ERK1/2) mitogen-activated protein kinases (MAPK) pathway. Activated PBMC, CD4 $4^{+} \mathrm{T}$ cells, JKT-FT7, or JKT-FT7 CCR6 GFP cells were treated with (a) hBD2 $(20 \mu \mathrm{g} / \mathrm{mL})$ or $(\mathbf{b})$ MIP- $3 \alpha(5 \mu \mathrm{g} / \mathrm{mL})$ for 1 and $5 \mathrm{~min}$. Phosphorylated ERK1/2 (p-ERK1/2) and total ERK1/2 were detected at the indicated time points by Western blotting. (c) Activated $\mathrm{CCR} 6^{+} \mathrm{CD} 4^{+} \mathrm{T}$ cells or CCR6 ${ }^{-} \mathrm{CD} 4^{+} \mathrm{T}$ cells were treated with PHA $(2.5 \mu \mathrm{g} / \mathrm{mL})$, hBD2 $(20 \mu \mathrm{g} / \mathrm{mL})$ or macrophage Inflammatory Protein-3 (MIP-3 $\alpha)(5 \mu \mathrm{g} / \mathrm{mL})$ for 1 and $5 \mathrm{~min}$. Phosphorylated ERK1/2 (p-ERK1/2) and total ERK1/2 were detected at the indicated time points by Western blotting. (d) Activated CD4 ${ }^{+} \mathrm{T}$ cells and JKT-FT7 CCR6 GFP were pre-treated with U0126 $(20 \mu \mathrm{M})$ for $1 \mathrm{~h}$ and then treated with PHA $(2.5 \mu \mathrm{g} / \mathrm{mL})$ or hBD2 $(20 \mu \mathrm{g} / \mathrm{mL})$ and probed for phosphorylated ERK1/2 and total ERK1/2. (e) Lysates from CD4 ${ }^{+} \mathrm{T}$ cells pre-treated with U0126 $(20 \mu \mathrm{M})$ and subsequently treated with hBD2 $(20 \mu \mathrm{g} / \mathrm{mL})$ were probed for APOBEC3G and $\beta$-actin by Western blotting. Images shown are representative of $2-4$ independent experiments from different donors or cell passages. 


\section{4. hBD2 Induces APOBEC3G Transcription}

We have demonstrated that $\mathrm{hBD} 2$ increases APOBEC3G protein expression and requires phosphorylation of ERK1/2. We previously showed that the post-entry inhibition of HIV-1 by hBD2 required the induction of $\mathrm{APOBEC} 3 \mathrm{G}$ and CCR6 expression [71]. To determine whether the increase in APOBEC3G by hBD2 is attributable to enhanced transcription, PHA activated primary $\mathrm{CD} 4^{+} \mathrm{T}$ cells were treated with hBD2 $(20 \mu \mathrm{g} / \mathrm{mL})$. hBD2 induced both a rapid transient increase in APOBEC3G mRNA as well as a 2-fold increase at $8 \mathrm{~h}$ (Figure 4a). To distinguish between transcription and RNA stability, cells were pre-treated with actinomycin D (ActD). Pre-treatment with ActD abrogated the increase in APOBEC3G mRNA at all timepoints (Figure 4a). These results suggest that hBD2 induces transcription of APOBEC3G mRNA. The post-entry inhibition and induction of APOBEC3G protein by hBD2 requires CCR6, so we next tested whether the same is true for the RNA expression. JKT-FT7 cells and JKT-FT7 CCR6 GFP cells were treated with hBD2 $(20 \mu \mathrm{g} / \mathrm{mL})$ and APOBEC3G mRNA levels were measured by qPCR. APOBEC3G mRNA expression was compared with untreated cells at matched timepoints and normalized to $18 \mathrm{~S}$ ribosomal RNA levels. Treatment with hBD2 increased APOBEC3G mRNA in JKT-FT7 CCR6 GFP cells but not in the JKT-FT7 cells (Figure 4b). These results are consistent with our findings that APOBEC3G protein induction is restricted to $\mathrm{CCR}^{+}$cells [71]. Similar to our findings in primary cells, we observed a rapid but transient increase in APOBEC3G mRNA following treatment with hBD2 in JKT-FT7 CCR6 GFP cells and a 2-fold increase occurring at $8 \mathrm{~h}$ (Figure 4b).

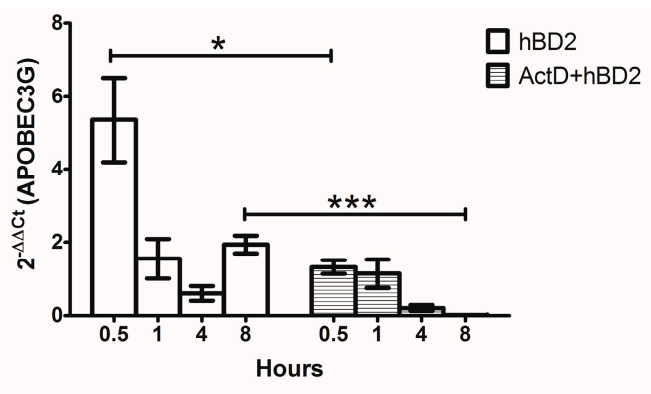

(a)

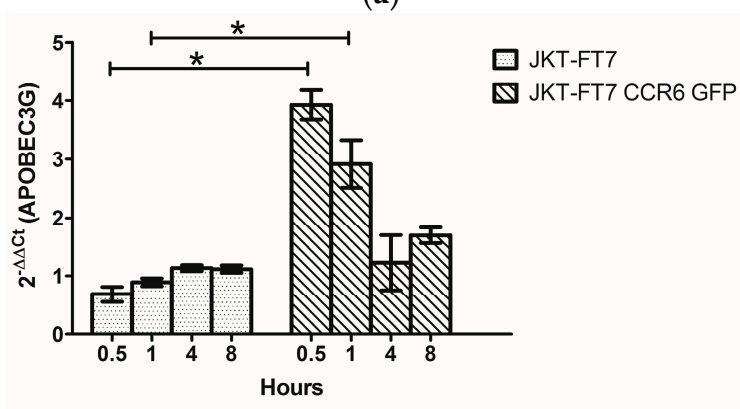

(b)

Figure 4. hBD2 induces transcription of APOBEC3G mRNA. (a) Primary CD4 ${ }^{+} \mathrm{T}$ cells were treated with hBD2 $(20 \mu \mathrm{g} / \mathrm{mL})$, pre-treated with actinomycin $\mathrm{D}(10 \mu \mathrm{g} / \mathrm{mL})$, or pre-treated with actinomycin $\mathrm{D}(10 \mu \mathrm{g} / \mathrm{mL})$ followed by treatment with hBD2 $(20 \mu \mathrm{g} / \mathrm{mL})$. APOBEC3G mRNA was assessed by quantitative real-time PCR comparing treated samples with untreated samples at matched timepoints. The data was normalized to $18 \mathrm{~S}$ ribosomal RNA and reflects the results from two different donors. Error bars representing SEM were included. (b) JKT-FT7 and JKT-FT7 CCR6 GFP cells were treated with hBD2 $(20 \mu \mathrm{g} / \mathrm{mL})$. A3G mRNA was assessed by quantitative real-time PCR comparing treated samples with untreated samples at matched timepoints. The data reflects the results of three independent experiments. Error bars representing SEM were included. Statistical analysis was performed by paired 2-tail Student $t$ test. ${ }^{*} p<0.05,{ }^{* * *} p<0.001$. 


\subsection{NFAT and IRF-4 Binding after hBD2 Treatment}

The transcription factors NFATc2, NFATc1, and IRF-4 regulate APOBEC3G in CD4 ${ }^{+} \mathrm{T}$ cells [88]. Therefore, we next determined by ChIP assay whether hBD2 $(20 \mu \mathrm{g} / \mathrm{mL})$ treatment induces NFATc2, NFATc1, and IRF-4 binding to the APOBEC3G promoter. We observed a 6.5-fold and 7.9-fold enrichment in NFATc2 and a 6.6 and 11.4-fold enrichment in NFATc1 bound to APOBEC3G promoter in hBD2 $(20 \mu \mathrm{g} / \mathrm{mL})$ treated JKT-FT7 CCR6 GFP cells at 30 and $60 \mathrm{~min}$, respectively. hBD2 treatment also yielded a 9.5-fold enrichment of IRF-4 bound to APOBEC3G promoter at $30 \mathrm{~min}$ (Figure 5). Thus, the increased nuclear localization of NFAT and increased IRF-4 expression after hBD2 treatment induced transcription of APOBEC3G in JKT-FT7 CCR6 GFP cells.
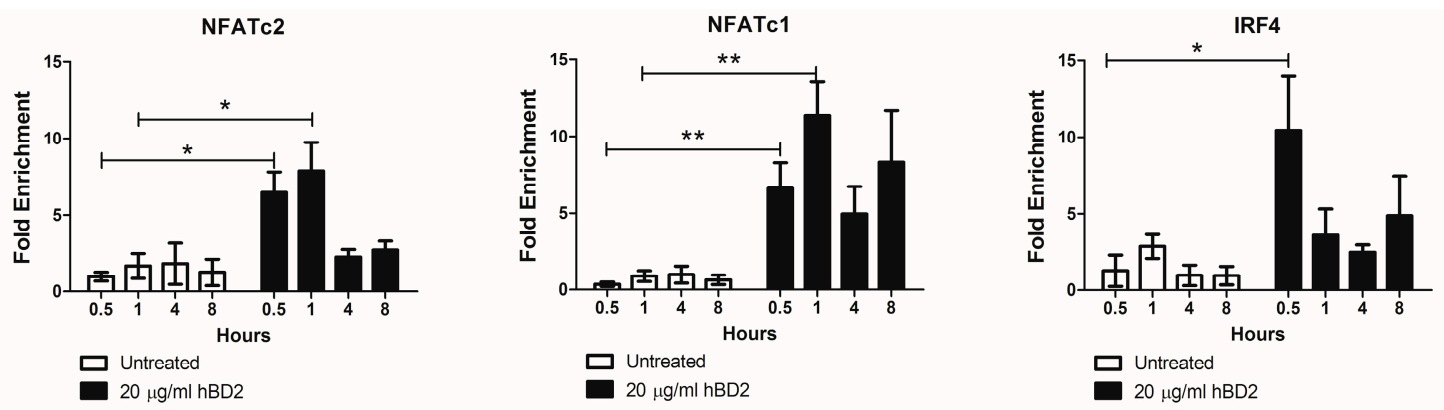

Figure 5. hBD2 enhances binding of NFAT and IRF-4 to the APOBEC3G promoter. JKT-FT7 CCR6 GFP cells were treated with hBD2 $(20 \mu \mathrm{g} / \mathrm{mL})$ for the indicated timepoints. Chromatin immunoprecipitation (ChIP) assays were performed using antibodies against NFATc2, NFATc1, or IRF-4. Immunoprecipitated DNA was detected by quantitative real-time PCR performed in triplicate. Shown is fold enrichment determined by comparison with IgG control of three independent experiments. Error bars representing SEM were included. Statistical analysis was performed by paired 2-tail Student $t$ test. ${ }^{*} p<0.05$, ** $p<0.01$.

\section{Discussion}

$\mathrm{CCR} 6^{+} \mathrm{CD} 4^{+} \mathrm{T}$ cells are comprised of a heterogeneous population of cells including Th17 cells that contribute to mucosal immune defenses. CCR6 is a critical receptor in gut homeostasis that is involved in trafficking of immature DCs, B cells, and T cells to sites of inflammation and into inductive sites within the GALT. A lack of CCR6 or its ligands, MIP-3 $\alpha$ or hBD2, is associated with immune dysfunction including reduced levels of intestinal $\mathrm{B}$ cells and regulatory $\mathrm{T}$ cells, diminished production of antigen specific IgA, and defects in T cell priming [4-8]. Structural defects are also associated with a lack of CCR6, MIP-3 $\alpha$, or hBD2 including smaller Peyer's patches with fewer B cells and follicular domes, reduced numbers of $\mathrm{M}$ cells, and a block in the development of isolated lymphoid follicles $[6,7,9]$. Similar defects in mucosal lymphoid development are observed in the absence of MIP-3 $\alpha$ or hBD2, suggesting non-redundant roles [3]. MIP-3 $\alpha$ recruits immune cells to inductive sites via CCR6 and is expressed by follicle-associated epithelium and CD90 ${ }^{+}$Th17 cells [89,90]. Although MIP- $3 \alpha$ inhibits HIV- 1 replication in vitro, MIP- $3 \alpha$ is strongly chemotactic for CCR6 ${ }^{+}$cells and therefore in vivo MIP- $3 \alpha$ may contribute to the spread of infection by recruiting these highly susceptible cells to sites of infection $[71,89]$. In SIV-infected rhesus macaques, $\mathrm{CCR} 6^{+} \mathrm{CD} 4^{+} \mathrm{T}$ cells are recruited from the periphery to the gut mucosa by MIP-3 $\alpha$. This disruption in $\mathrm{CCR} 6^{+} \mathrm{CD} 4^{+} \mathrm{T}$ cell homeostasis may expand the number of highly susceptible viral targets in the gut mucosa [24]. Interestingly, glycerol monolaurate, an antimicrobial that inhibits production of proinflammatory cytokines and MIP-3 $\alpha$, protects rhesus macaques from mucosal SIV transmission [89]. In contrast, hBD2 may prevent the spread of infection, as it directly inhibits HIV and induces APOBEC3G, but is weakly chemotactic for $\mathrm{CCR}^{+}$cells compared with MIP-3 $\alpha[70,71]$.

$\mathrm{CCR}^{+} \mathrm{CD}^{+} \mathrm{T}$ cells and Th17 cells are redistributed from peripheral blood and preferentially depleted from the GALT, which correlates with disease progression $[1,2,13,14,17,21,24,90]$. 
The connections between CCR6, its ligands, and Th17 cells are multiple and highly relevant in the context of HIV infection. Th17 cells are an important component of mucosal immune defenses against extracellular and intracellular bacteria and fungi [32,34]. IL-17 limits microbes through the induction of pro-inflammatory cytokines, chemokines that recruit innate and adaptive immune cells, proteins involved in enterocyte homeostasis and antimicrobial peptides such as hBD2 [36-39,41,42,91,92]. Limiting microbial threats, maintenance, and re-establishment of the mucosal barrier are vital for intestinal homeostasis and prevention of microbial translocation. It has been shown that $\mathrm{CCR}^{+} \mathrm{CCR} 4^{+}$, $\mathrm{CCR}^{+}{ }^{+} \mathrm{CXCR} 3^{+}$and $\mathrm{CCR} 6^{+} \mathrm{CD} 90^{+}$Th17 cell subsets are highly permissive to HIV- 1 infection $[2,90]$. Th17 cells can also convert into follicular T helper cells $\left(\mathrm{T}_{\mathrm{FH}}\right)$, a cell type that is highly infectible by HIV and SIV, despite expressing low levels of CCR5 [93-96]. It is possible that Th17 CCR6 ${ }^{+}$cells may get initially infected, and then convert to $\mathrm{T}_{\mathrm{FH}}$ cells. Interestingly, $\mathrm{CCR} 6^{+} \mathrm{CCR} 4^{+} \mathrm{Th} 17$ cells are specific for Candida albicans and CCR6 ${ }^{+} \mathrm{CXCR} 3^{+}$Th17 cells are specific for Mycobacterium tuberculosis, two HIV-1 associated infections [11]. Thus, the preferential depletion of CCR6 $6^{+} \mathrm{T}$ cells may be a key event in the pathogenesis of HIV infection (Figure 6) [11,97].
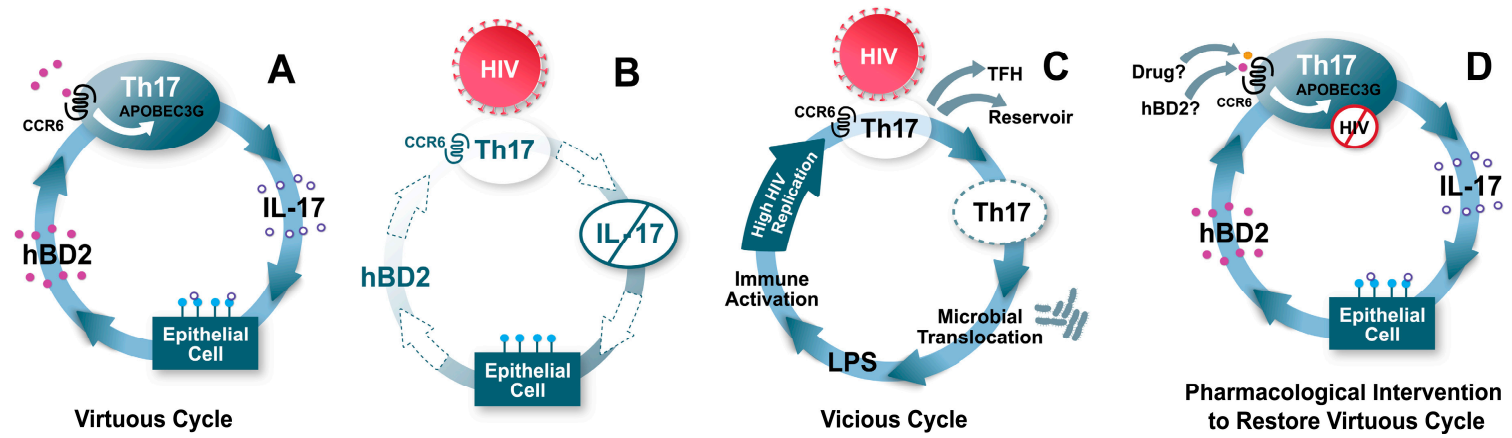

Figure 6. Model: hBD2 contributes to a "virtuous cycle", maintaining mucosal integrity and protecting CCR6 $^{+}$T cells. (A) CCR6 ${ }^{+}$T cells include Th17 cells, which produce IL-17. IL-17 has several effects on mucosal epithelia, including regulation of tight junctions, and induction of the antimicrobial peptide hBD2. hBD2 binding to CCR6 induces intracellular signaling events leading to increased transcription of APOBEC3G, which inhibits HIV intracellularly. (B) When HIV reaches CCR6 ${ }^{+}$Th17 cells due to breaches in the mucosa, their death causes loss of production of IL-17, and hBD2 production is also decreased as a consequence. Thus, $\mathrm{CCR}^{+} \mathrm{T}$ cells become more permissive to HIV infection. (C) The loss of mucosal integrity due to lower levels of Th17 and hBD2 result in microbial translocation. High levels of lipopolysaccharide (LPS) and other microbial factors cause immune activation, which further enhance HIV replication, eventuating in a self-perpetuating "vicious cycle". (D) Induction or administration of adequate levels of hBD2, or a pharmaceutical drug targeting CCR6 could result in high levels of expression of APOBEC3G and protection of CCR6 ${ }^{+}$Th17 cells.

We have previously reported that hBD2 inhibits HIV-1 replication post-entry requiring induction of APOBEC3G via CCR6 [71]. Here, we found that hBD2 selectively inhibits HIV replication in CCR6 ${ }^{+}$ $\mathrm{CD}^{+}$cells, but not in $\mathrm{CCR} 6^{-} \mathrm{CD}^{+}$cells. As expected, the levels of HIV replication in $\mathrm{CCR} 6^{-} \mathrm{CD}^{+}$ cells were significantly lower than in $\mathrm{CCR}^{+}{ }^{+} \mathrm{CD} 4^{+}$cells; however, that low level of replication could not be inhibited by treating cells with azidothymidine (AZT), a reverse transcriptase inhibitor. One intriguing possibility is that this low level of reverse-transcription independent replication may lead to HIV latency, making the $\mathrm{CCR}^{-} \mathrm{CD}^{+}$cells a possible reservoir. In this study, we analyzed the status (LMM versus HMM) of APOBEC3G and identified the hBD2-induced signaling pathway and transcription factors that result in its increased expression and selective protection of CCR $6^{+} \mathrm{CD} 4^{+}$ cells. We found that hBD2 causes a dramatic shift from the HMM to the highly active LMM form in $\mathrm{CCR}^{+}$Jurkat cells, but not in primary $\mathrm{CD}^{+} \mathrm{T}$ cells. It is possible that the lack of shift from HMM to LMM is due to the lack of depolimerization in CCR6 ${ }^{-}$cells, however due to cell number limitations, the molecular mass of APOBEC $3 \mathrm{G}$ was not determined in primary cells separated into 
$\mathrm{CCR}^{+}$and CCR6 ${ }^{-}$subsets. Alternatively, it is possible that differences in signaling pathways between Jurkat and primary cells may be responsible for this difference. Treatment with hBD2 resulted in ERK1/2 phosphorylation in PBMC, CD4 ${ }^{+} \mathrm{T}$ cells, and JKT-FT7 CCR6 GFP cells and was required for APOBEC3G expression. We observed rapid transcriptional activation of APOBEC3G, which was sensitive to treatment with the transcriptional inhibitor actinomycin $\mathrm{D}$, in both primary $\mathrm{CD} 4^{+}$ T cells and JKT-FT7 CCR6 GFP cells. In contrast, hBD2 did not induce APOBEC3G in the CCR6JKT-FT7 cells. The rapid transcriptional induction of APOBEC3G mRNA confirms the results from our ChIP experiments. We found enrichment of APOBEC3G promoter sequence pulled down with NFATc2, NFATc1, and IRF-4 antibodies at early timepoints. NFAT proteins cooperate with additional transcription factors and Farrow et al. identified an NFAT/IRF-4 composite site in the APOBEC3G promoter [88]. NFAT and IRF-4 induce APOBEC3G expression, which is markedly enhanced upon cooperative binding [88]. Our results suggest that the early increase in APOBEC3G mRNA after hBD2 treatment is due to the presence of both NFAT and IRF-4.

The preferential infection of CCR6 $6^{+}$Th17 cells may be attributable to the higher expression of the viral receptors CD4, CXCR4, and $\alpha 4 \beta 7$ compared with CCR6 ${ }^{-}$Th17 cells resulting in enhanced HIV envelope binding [14]. Despite similar CCR5 expression levels, CCR6 ${ }^{+}$Th17 cells may be more susceptible to 5 tropic virus, partly due to low expression of CCR5 ligands and decreased expression of antiviral factors [14,16]. The preferential infection and depletion of $\mathrm{CCR}^{+} \mathrm{CD}^{+} \mathrm{T}$ cell subsets may initiate or contribute to the failure of the gut mucosal immune system. HIV-1-infected long-term non-progressors and SIV-infected sooty mangabeys, which do not progress to AIDS and lack both microbial translocation and chronic immune activation, maintain levels of Th17 cells in both the blood and gut $[21,28,30]$. These findings suggest that protecting $\mathrm{CCR} 6^{+} \mathrm{CD} 4^{+} \mathrm{T}$ cell subsets may be critical in preventing disease progression, and hBD2 produced from mucosal epithelial cells could contribute to preserving this subset (Figure 6). Consistent with this hypothesis, a recent study has highlighted that hBD2 is a key factor differentially expressed in primary endometrial epithelial cells (which produce protective factors), as compared to endometrial stromal fibroblasts (which enhance HIV infection in vitro) [98].

In agreement with previously reported findings, we found that $\mathrm{CCR} 6^{+} \mathrm{CD} 4^{+} \mathrm{T}$ cells have higher levels of replication when infected with pNL4-3-deltaE-EGFP HIV pseudotyped with the AMLV envelope which does not use HIV receptors or CCR6 for entry $[16,17]$. In addition to the previously reported elevated levels of HIV receptors and decreased CCR5 ligands, these findings suggest that additional post-entry cellular factors contribute to the preferential infection of $\mathrm{CCR}^{+}$cells. The CCR6-mediated intracellular inhibition of HIV-1 by hBD2 described herein, provides insight into signaling pathways that may guide the development of therapeutics that selectively target and protect $\mathrm{CCR6}^{+}$cells.

\section{Conclusions}

Our study shows that $\mathrm{hBD} 2$ protects $\mathrm{CCR} 6^{+} \mathrm{CD} 4^{+} \mathrm{T}$ cells from HIV infection. The protection is associated with increased APOBEC3G transcription, due to ERK1/2 signaling. Since there is increasing evidence that $\mathrm{CCR} 6^{+} \mathrm{CD} 4^{+}$cells are lost early in HIV infection, our results are important to devise novel strategy to combat HIV infection. One attractive possibility is to design drugs that bind to CCR6 inducing APOBEC3G transcription. hBD2 has low chemotactic activity, so that it is conceivable that a novel CCR6-binding drug could induce APOBEC3G expression, and have low chemotactic index. Such drug could target HIV even in the latent reservoir, which has been shown to include CCR6 ${ }^{+}$cells.

Acknowledgments: We thank Marvin Reitz for his critical reading of this manuscript. We are grateful to Richard Koup, Ferenc Livak, Nicholas Carbonetti, Yutaka Tagaya and Jennifer Bharucha for helpful discussions and suggestions. We thank Holly Morgan Barnard for her artwork. We also thank the AIDS Research and Reference Reagent Program, Division of AIDS. This work was supported by the National Institute of Neurological Disorders And Stroke award R01NS066842 to Alfredo Garzino-Demo. Aaron Christensen-Quick was a trainee under Institutional Training Grant 1T32AI095190-01A1 from the National Institute of Allergy and Infectious Diseases. Mark K. Lafferty was a trainee under Institutional Training Grant T32AI007540 from the National 
Institute of Allergy and Infectious Diseases. The content is solely the responsibility of the authors and does not necessarily represent the official views of the National Institute of Allergy and Infectious Diseases, the National Institute of Neurological Disorders And Stroke, or the National Institutes of Health. The authors declare no conflict of interest exists.

Author Contributions: M.K.L. and A.G.-D. conceived and designed the experiments; M.K.L., L.S., and A.C.-Q. performed the experiments; M.K.L. analyzed the data; W.L. contributed reagents/materials; M.K.L. and A.G.-D. wrote the paper.

Conflicts of Interest: The authors declare no conflict of interest. The funding sponsors had no role in the design of the study; in the collection, analyses, or interpretation of data; in the writing of the manuscript, and in the decision to publish the results.

\section{References}

1. Lecureuil, C.; Combadiere, B.; Mazoyer, E.; Bonduelle, O.; Samri, A.; Autran, B.; Debre, P.; Combadiere, C. Trapping and apoptosis of novel subsets of memory $\mathrm{T}$ lymphocytes expressing CCR6 in the spleen of HIV-infected patients. Blood 2007, 109, 3649-3657. [CrossRef] [PubMed]

2. Gosselin, A.; Monteiro, P.; Chomont, N.; Diaz-Griffero, F.; Said, E.A.; Fonseca, S.; Wacleche, V.; El-Far, M.; Boulassel, M.R.; Routy, J.P.; et al. Peripheral blood CCR4 ${ }^{+} \mathrm{CCR} 6^{+}$and $\mathrm{CXCR} 3^{+} \mathrm{CCR} 6^{+} \mathrm{CD} 4^{+} \mathrm{T}$ cells are highly permissive to HIV-1 infection. J. Immunol. 2010, 184, 1604-1616. [CrossRef] [PubMed]

3. Bouskra, D.; Brezillon, C.; Berard, M.; Werts, C.; Varona, R.; Boneca, I.G.; Eberl, G. Lymphoid tissue genesis induced by commensals through NOD1 regulates intestinal homeostasis. Nature 2008, 456, 507-510. [CrossRef] [PubMed]

4. Cook, D.N.; Prosser, D.M.; Forster, R.; Zhang, J.; Kuklin, N.A.; Abbondanzo, S.J.; Niu, X.D.; Chen, S.C.; Manfra, D.J.; Wiekowski, M.T.; et al. CCR6 mediates dendritic cell localization, lymphocyte homeostasis, and immune responses in mucosal tissue. Immunity 2000, 12, 495-503. [CrossRef]

5. Le Borgne, M.; Etchart, N.; Goubier, A.; Lira, S.A.; Sirard, J.C.; van Rooijen, N.; Caux, C.; Ait-Yahia, S.; Vicari, A.; Kaiserlian, D.; et al. Dendritic cells rapidly recruited into epithelial tissues via CCR6/CCL20 are responsible for $\mathrm{CD}^{+} \mathrm{T}$ cell crosspriming in vivo. Immunity 2006, 24, 191-201. [CrossRef] [PubMed]

6. $\quad$ Lugering, A.; Floer, M.; Westphal, S.; Maaser, C.; Spahn, T.W.; Schmidt, M.A.; Domschke, W.; Williams, I.R.; Kucharzik, T. Absence of CCR6 inhibits $\mathrm{CD}^{+}$regulatory T-cell development and M-cell formation inside peyer's patches. Am. J. Pathol. 2005, 166, 1647-1654. [CrossRef]

7. McDonald, K.G.; McDonough, J.S.; Wang, C.; Kucharzik, T.; Williams, I.R.; Newberry, R.D. CC chemokine receptor 6 expression by $\mathrm{B}$ lymphocytes is essential for the development of isolated lymphoid follicles. Am. J. Pathol. 2007, 170, 1229-1240. [CrossRef] [PubMed]

8. Sallusto, F.; Lanzavecchia, A.; Mackay, C.R. Chemokines and chemokine receptors in T-cell priming and Th1/Th2-mediated responses. Immunol. Today 1998, 19, 568-574. [CrossRef]

9. Williams, I.R. CCR6 and CCL20: Partners in intestinal immunity and lymphorganogenesis. Ann. N. Y. Acad. Sci. 2006, 1072, 52-61. [CrossRef] [PubMed]

10. Liao, F.; Rabin, R.L.; Smith, C.S.; Sharma, G.; Nutman, T.B.; Farber, J.M. CC-chemokine receptor 6 is expressed on diverse memory subsets of $\mathrm{T}$ cells and determines responsiveness to macrophage inflammatory protein 3 alpha. J. Immunol. 1999, 162, 186-194. [PubMed]

11. Acosta-Rodriguez, E.V.; Rivino, L.; Geginat, J.; Jarrossay, D.; Gattorno, M.; Lanzavecchia, A.; Sallusto, F.; Napolitani, G. Surface phenotype and antigenic specificity of human interleukin 17-producing $\mathrm{T}$ helper memory cells. Nat. Immunol. 2007, 8, 639-646. [CrossRef] [PubMed]

12. Singh, S.P.; Zhang, H.H.; Foley, J.F.; Hedrick, M.N.; Farber, J.M. Human T cells that are able to produce IL-17 express the chemokine receptor CCR6. J. Immunol. 2008, 180, 214-221. [CrossRef] [PubMed]

13. El Hed, A.; Khaitan, A.; Kozhaya, L.; Manel, N.; Daskalakis, D.; Borkowsky, W.; Valentine, F.; Littman, D.R.; Unutmaz, D. Susceptibility of human Th17 cells to human immunodeficiency virus and their perturbation during infection. J. Infect. Dis. 2010, 201, 843-854. [CrossRef] [PubMed]

14. Alvarez, Y.; Tuen, M.; Shen, G.; Nawaz, F.; Arthos, J.; Wolff, M.J.; Poles, M.A.; Hioe, C.E. Preferential HIV infection of CCR6 $6^{+}$Th17 cells is associated with higher levels of virus receptor expression and lack of CCR5 ligands. J. Virol. 2013, 87, 10843-10854. [CrossRef] [PubMed] 
15. Guan, Y.; Abdelwahab, S.; Kamin-Lewis, R.; DeVico, A.L.; Lewis, G.K. Self-protection of individual CD4 ${ }^{+}$ T cells against R5 HIV-1 infection by the synthesis of anti-viral CCR5 ligands. PLoS ONE 2008, 3, e3481. [CrossRef] [PubMed]

16. Christensen-Quick, A.; Lafferty, M.; Sun, L.; Marchionni, L.; DeVico, A.; Garzino-Demo, A. Human Th17 cells lack HIV-inhibitory rnases and are highly permissive to productive HIV infection. J. Virol. 2016, 90, 7833-7847. [CrossRef] [PubMed]

17. Monteiro, P.; Gosselin, A.; Wacleche, V.S.; El-Far, M.; Said, E.A.; Kared, H.; Grandvaux, N.; Boulassel, M.R.; Routy, J.P.; Ancuta, P. Memory CCR6 ${ }^{+} \mathrm{CD}^{+}{ }^{+} \mathrm{T}$ cells are preferential targets for productive HIV type 1 infection regardless of their expression of integrin beta7. J. Immunol. 2011, 186, 4618-4630. [CrossRef] [PubMed]

18. Khoury, G.; Anderson, J.L.; Fromentin, R.; Hartogenesis, W.; Smith, M.Z.; Bacchetti, P.; Hecht, F.M.; Chomont, N.; Cameron, P.U.; Deeks, S.G.; et al. Persistence of integrated HIV DNA in CXCR3 ${ }^{+}$CCR6 $^{+}$ memory CD4 ${ }^{+} \mathrm{T}$ cells in HIV-infected individuals on antiretroviral therapy. AIDS 2016, 30, 1511-1520. [CrossRef] [PubMed]

19. Wacleche, V.S.; Goulet, J.P.; Gosselin, A.; Monteiro, P.; Soudeyns, H.; Fromentin, R.; Jenabian, M.A.; Vartanian, S.; Deeks, S.G.; Chomont, N.; et al. New insights into the heterogeneity of Th17 subsets contributing to HIV-1 persistence during antiretroviral therapy. Retrovirology 2016, 13, 59. [CrossRef] [PubMed]

20. Gosselin, A.; Wiche Salinas, T.R.; Planas, D.; Wacleche, V.S.; Zhang, Y.; Fromentin, R.; Chomont, N.; Cohen, E.A.; Shacklett, B.; Mehraj, V.; et al. HIV persists in CCR6 ${ }^{+} \mathrm{CD} 4^{+} \mathrm{T}$ cells from colon and blood during antiretroviral therapy. AIDS 2017, 31, 35-48. [CrossRef] [PubMed]

21. Brenchley, J.M.; Paiardini, M.; Knox, K.S.; Asher, A.I.; Cervasi, B.; Asher, T.E.; Scheinberg, P.; Price, D.A.; Hage, C.A.; Kholi, L.M.; et al. Differential Th17 CD4 T-cell depletion in pathogenic and nonpathogenic lentiviral infections. Blood 2008, 112, 2826-2835. [CrossRef] [PubMed]

22. Cecchinato, V.; Trindade, C.J.; Laurence, A.; Heraud, J.M.; Brenchley, J.M.; Ferrari, M.G.; Zaffiri, L.; Tryniszewska, E.; Tsai, W.P.; Vaccari, M.; et al. Altered balance between Th17 and Th1 cells at mucosal sites predicts aids progression in simian immunodeficiency virus-infected macaques. Mucosal Immunol. 2008, 1, 279-288. [CrossRef] [PubMed]

23. Stieh, D.J.; Matias, E.; Xu, H.; Fought, A.J.; Blanchard, J.L.; Marx, P.A.; Veazey, R.S.; Hope, T.J. Th17 cells are preferentially infected very early after vaginal transmission of SIV in macaques. Cell Host Microbe 2016, 19, 529-540. [CrossRef] [PubMed]

24. McGary, C.S.; Alvarez, X.; Harrington, S.; Cervasi, B.; Ryan, E.S.; Iriele, R.I.; Paganini, S.; Harper, J.L.; Easley, K.; Silvestri, G.; et al. The loss of CCR6 ${ }^{+}$and CD161 ${ }^{+} \mathrm{CD} 4^{+} \mathrm{T}$-cell homeostasis contributes to disease progression in SIV-infected rhesus macaques. Mucosal Immunol. 2017. [CrossRef] [PubMed]

25. Brenchley, J.M.; Schacker, T.W.; Ruff, L.E.; Price, D.A.; Taylor, J.H.; Beilman, G.J.; Nguyen, P.L.; Khoruts, A.; Larson, M.; Haase, A.T.; et al. Cd4 ${ }^{+}$T cell depletion during all stages of HIV disease occurs predominantly in the gastrointestinal tract. J. Exp. Med. 2004, 200, 749-759. [CrossRef] [PubMed]

26. Mehandru, S.; Poles, M.A.; Tenner-Racz, K.; Horowitz, A.; Hurley, A.; Hogan, C.; Boden, D.; Racz, P.; Markowitz, M. Primary HIV-1 infection is associated with preferential depletion of CD4 ${ }^{+} \mathrm{T}$ lymphocytes from effector sites in the gastrointestinal tract. J. Exp. Med. 2004, 200, 761-770. [CrossRef] [PubMed]

27. Mehandru, S.; Poles, M.A.; Tenner-Racz, K.; Jean-Pierre, P.; Manuelli, V.; Lopez, P.; Shet, A.; Low, A.; Mohri, H.; Boden, D.; et al. Lack of mucosal immune reconstitution during prolonged treatment of acute and early HIV-1 infection. PLoS Med. 2006, 3, e484. [CrossRef]

28. Brenchley, J.M.; Price, D.A.; Schacker, T.W.; Asher, T.E.; Silvestri, G.; Rao, S.; Kazzaz, Z.; Bornstein, E.; Lambotte, O.; Altmann, D.; et al. Microbial translocation is a cause of systemic immune activation in chronic HIV infection. Nat. Med. 2006, 12, 1365-1371. [CrossRef] [PubMed]

29. Raffatellu, M.; Santos, R.L.; Verhoeven, D.E.; George, M.D.; Wilson, R.P.; Winter, S.E.; Godinez, I.; Sankaran, S.; Paixao, T.A.; Gordon, M.A.; et al. Simian immunodeficiency virus-induced mucosal interleukin-17 deficiency promotes salmonella dissemination from the gut. Nat. Med. 2008, 14, 421-428. [CrossRef] [PubMed]

30. Ciccone, E.J.; Greenwald, J.H.; Lee, P.I.; Biancotto, A.; Read, S.W.; Yao, M.A.; Hodge, J.N.; Thompson, W.L.; Kovacs, S.B.; Chairez, C.L.; et al. CD4 ${ }^{+} \mathrm{T}$ cells, including Th17 and cycling subsets, are intact in the gut mucosa of HIV-1-infected long-term nonprogressors. J. Virol. 2011, 85, 5880-5888. [CrossRef] [PubMed] 
31. Chege, D.; Sheth, P.M.; Kain, T.; Kim, C.J.; Kovacs, C.; Loutfy, M.; Halpenny, R.; Kandel, G.; Chun, T.W.; Ostrowski, M.; et al. Sigmoid Th17 populations, the HIV latent reservoir, and microbial translocation in men on long-term antiretroviral therapy. AIDS 2011, 25, 741-749. [CrossRef] [PubMed]

32. Curtis, M.M.; Way, S.S. Interleukin-17 in host defence against bacterial, mycobacterial and fungal pathogens. Immunology 2009, 126, 177-185. [CrossRef] [PubMed]

33. Conti, H.R.; Shen, F.; Nayyar, N.; Stocum, E.; Sun, J.N.; Lindemann, M.J.; Ho, A.W.; Hai, J.H.; Yu, J.J.; Jung, J.W.; et al. Th17 cells and IL-17 receptor signaling are essential for mucosal host defense against oral candidiasis. J. Exp. Med. 2009, 206, 299-311. [CrossRef] [PubMed]

34. Klatt, N.R.; Brenchley, J.M. Th17 cell dynamics in HIV infection. Curr. Opin. HIV AIDS 2010, 5, $135-140$. [CrossRef] [PubMed]

35. Hernandez-Santos, N.; Huppler, A.R.; Peterson, A.C.; Khader, S.A.; McKenna, K.C.; Gaffen, S.L. Th17 cells confer long-term adaptive immunity to oral mucosal Candida albicans infections. Mucosal Immunol. 2013, 6, 900-910. [CrossRef] [PubMed]

36. Fossiez, F.; Djossou, O.; Chomarat, P.; Flores-Romo, L.; Ait-Yahia, S.; Maat, C.; Pin, J.J.; Garrone, P.; Garcia, E.; Saeland, S.; et al. T cell interleukin-17 induces stromal cells to produce proinflammatory and hematopoietic cytokines. J. Exp. Med. 1996, 183, 2593-2603. [CrossRef] [PubMed]

37. LeGrand, A.; Fermor, B.; Fink, C.; Pisetsky, D.S.; Weinberg, J.B.; Vail, T.P.; Guilak, F. Interleukin-1, tumor necrosis factor alpha, and interleukin-17 synergistically up-regulate nitric oxide and prostaglandin E2 production in explants of human osteoarthritic knee menisci. Arthritis Rheum. 2001, 44, 2078-2083. [CrossRef]

38. Moseley, T.A.; Haudenschild, D.R.; Rose, L.; Reddi, A.H. Interleukin-17 family and IL-17 receptors. Cytokine Growth Factor Rev. 2003, 14, 155-174. [CrossRef]

39. Ye, P.; Rodriguez, F.H.; Kanaly, S.; Stocking, K.L.; Schurr, J.; Schwarzenberger, P.; Oliver, P.; Huang, W.; Zhang, P.; Zhang, J.; et al. Requirement of interleukin 17 receptor signaling for lung CXC chemokine and granulocyte colony-stimulating factor expression, neutrophil recruitment, and host defense. J. Exp. Med. 2001, 194, 519-527. [CrossRef] [PubMed]

40. Chen, Y.; Thai, P.; Zhao, Y.H.; Ho, Y.S.; DeSouza, M.M.; Wu, R. Stimulation of airway mucin gene expression by interleukin (IL)-17 through IL-6 paracrine/autocrine loop. J. Biol. Chem. 2003, 278, 17036-17043. [CrossRef] [PubMed]

41. Kao, C.Y.; Chen, Y.; Thai, P.; Wachi, S.; Huang, F.; Kim, C.; Harper, R.W.; Wu, R. IL-17 markedly up-regulates beta-defensin-2 expression in human airway epithelium via JAK and NF-kappaB signaling pathways. J. Immunol. 2004, 173, 3482-3491. [CrossRef] [PubMed]

42. Kao, C.Y.; Huang, F.; Chen, Y.; Thai, P.; Wachi, S.; Kim, C.; Tam, L.; Wu, R. Up-regulation of CC chemokine ligand 20 expression in human airway epithelium by IL-17 through a JAK-independent but MEK/NF-KappaB-dependent signaling pathway. J. Immunol. 2005, 175, 6676-6685. [CrossRef] [PubMed]

43. Kinugasa, T.; Sakaguchi, T.; Gu, X.; Reinecker, H.C. Claudins regulate the intestinal barrier in response to immune mediators. Gastroenterology 2000, 118, 1001-1011. [CrossRef]

44. Liang, S.C.; Tan, X.Y.; Luxenberg, D.P.; Karim, R.; Dunussi-Joannopoulos, K.; Collins, M.; Fouser, L.A. Interleukin (IL)-22 and IL-17 are coexpressed by Th17 cells and cooperatively enhance expression of antimicrobial peptides. J. Exp. Med. 2006, 203, 2271-2279. [CrossRef] [PubMed]

45. Wolk, K.; Kunz, S.; Witte, E.; Friedrich, M.; Asadullah, K.; Sabat, R. IL-22 increases the innate immunity of tissues. Immunity 2004, 21, 241-254. [CrossRef] [PubMed]

46. Lehrer, R.I.; Ganz, T.; Selsted, M.E. Defensins: Endogenous antibiotic peptides of animal cells. Cell 1991, 64, 229-230. [CrossRef]

47. Zasloff, M. Antibiotic peptides as mediators of innate immunity. Curr. Opin. Immunol. 1992, 4, 3-7. [CrossRef]

48. Ganz, T. Defensins: Antimicrobial peptides of innate immunity. Nat. Rev. Immunol. 2003, 3, 710-720. [CrossRef] [PubMed]

49. Selsted, M.E.; Ouellette, A.J. Mammalian defensins in the antimicrobial immune response. Nat. Immunol. 2005, 6, 551-557. [CrossRef] [PubMed]

50. Chen, H.; Xu, Z.; Peng, L.; Fang, X.; Yin, X.; Xu, N.; Cen, P. Recent advances in the research and development of human defensins. Peptides 2006, 27, 931-940. [CrossRef] [PubMed]

51. Pazgier, M.; Hoover, D.M.; Yang, D.; Lu, W.; Lubkowski, J. Human beta-defensins. Cell. Mol. Life Sci. 2006, 63, 1294-1313. [CrossRef] [PubMed] 
52. Ding, J.; Chou, Y.Y.; Chang, T.L. Defensins in viral infections. J. Innate Immun. 2009, 1, 413-420. [CrossRef] [PubMed]

53. Wilson, S.S.; Wiens, M.E.; Smith, J.G. Antiviral mechanisms of human defensins. J. Mol. Biol. 2013, 425, 4965-4980. [CrossRef] [PubMed]

54. Bevins, C.L. Innate immune functions of alpha-defensins in the small intestine. Dig. Dis. 2013, 31, $299-304$. [CrossRef] [PubMed]

55. Daher, K.A.; Selsted, M.E.; Lehrer, R.I. Direct inactivation of viruses by human granulocyte defensins. J. Virol. 1986, 60, 1068-1074. [PubMed]

56. Chang, T.L.; Klotman, M.E. Defensins: Natural anti-HIV peptides. AIDS Rev. 2004, 6, 161-168. [PubMed]

57. Garzino-Demo, A. Chemokines and defensins as HIV suppressive factors: An evolving story. Curr. Pharm. Des. 2007, 13, 163-172. [CrossRef] [PubMed]

58. Yang, D.; Chertov, O.; Bykovskaia, S.N.; Chen, Q.; Buffo, M.J.; Shogan, J.; Anderson, M.; Schroder, J.M.; Wang, J.M.; Howard, O.M.; et al. Beta-defensins: Linking innate and adaptive immunity through dendritic and T cell CCR6. Science 1999, 286, 525-528. [CrossRef] [PubMed]

59. Wu, Z.; Hoover, D.M.; Yang, D.; Boulegue, C.; Santamaria, F.; Oppenheim, J.J.; Lubkowski, J.; Lu, W. Engineering disulfide bridges to dissect antimicrobial and chemotactic activities of human beta-defensin 3. Proc. Natl. Acad. Sci. USA 2003, 100, 8880-8885. [CrossRef] [PubMed]

60. Niyonsaba, F.; Ogawa, H.; Nagaoka, I. Human beta-defensin-2 functions as a chemotactic agent for tumour necrosis factor-alpha-treated human neutrophils. Immunology 2004, 111, 273-281. [CrossRef] [PubMed]

61. Soruri, A.; Grigat, J.; Forssmann, U.; Riggert, J.; Zwirner, J. Beta-defensins chemoattract macrophages and mast cells but not lymphocytes and dendritic cells: CCR6 is not involved. Eur. J. Immunol. 2007, 37, 2474-2486. [CrossRef] [PubMed]

62. Barabas, N.; Rohrl, J.; Holler, E.; Hehlgans, T. Beta-defensins activate macrophages and synergize in pro-inflammatory cytokine expression induced by TLR ligands. Immunobiology 2013, 218, 1005-1011. [CrossRef] [PubMed]

63. Rohrl, J.; Yang, D.; Oppenheim, J.J.; Hehlgans, T. Human beta-defensin 2 and 3 and their mouse orthologs induce chemotaxis through interaction with CCR2. J. Immunol. 2010, 184, 6688-6694. [CrossRef] [PubMed]

64. Boniotto, M.; Jordan, W.J.; Eskdale, J.; Tossi, A.; Antcheva, N.; Crovella, S.; Connell, N.D.; Gallagher, G. Human beta-defensin 2 induces a vigorous cytokine response in peripheral blood mononuclear cells. Antimicrob. Agents Chemother. 2006, 50, 1433-1441. [CrossRef] [PubMed]

65. Niyonsaba, F.; Ushio, H.; Nakano, N.; Ng, W.; Sayama, K.; Hashimoto, K.; Nagaoka, I.; Okumura, K.; Ogawa, H. Antimicrobial peptides human beta-defensins stimulate epidermal keratinocyte migration, proliferation and production of proinflammatory cytokines and chemokines. J. Investig. Dermatol. 2007, 127, 594-604. [CrossRef] [PubMed]

66. Chen, X.; Niyonsaba, F.; Ushio, H.; Hara, M.; Yokoi, H.; Matsumoto, K.; Saito, H.; Nagaoka, I.; Ikeda, S.; Okumura, K.; et al. Antimicrobial peptides human beta-defensin (HBD)-3 and HBD-4 activate mast cells and increase skin vascular permeability. Eur. J. Immunol. 2007, 37, 434-444. [CrossRef] [PubMed]

67. Otte, J.M.; Werner, I.; Brand, S.; Chromik, A.M.; Schmitz, F.; Kleine, M.; Schmidt, W.E. Human beta defensin 2 promotes intestinal wound healing in vitro. J. Cell. Biochem. 2008, 104, 2286-2297. [CrossRef] [PubMed]

68. Weinberg, A.; Jin, G.; Sieg, S.; McCormick, T.S. The yin and yang of human beta-defensins in health and disease. Front. Immunol. 2012, 3, 294. [CrossRef] [PubMed]

69. Quinones-Mateu, M.E.; Lederman, M.M.; Feng, Z.; Chakraborty, B.; Weber, J.; Rangel, H.R.; Marotta, M.L.; Mirza, M.; Jiang, B.; Kiser, P.; et al. Human epithelial beta-defensins 2 and 3 inhibit HIV-1 replication. AIDS 2003, 17, F39-F48. [CrossRef] [PubMed]

70. Sun, L.; Finnegan, C.M.; Kish-Catalone, T.; Blumenthal, R.; Garzino-Demo, P.; La Terra Maggiore, G.M.; Berrone, S.; Kleinman, C.; Wu, Z.; Abdelwahab, S.; et al. Human beta-defensins suppress human immunodeficiency virus infection: Potential role in mucosal protection. J. Virol. 2005, 79, 14318-14329. [CrossRef] [PubMed]

71. Lafferty, M.K.; Sun, L.; DeMasi, L.; Lu, W.; Garzino-Demo, A. CCR6 ligands inhibit HIV by inducing APOBEC3G. Blood 2010, 115, 1564-1571. [CrossRef] [PubMed]

72. Sheehy, A.M.; Gaddis, N.C.; Choi, J.D.; Malim, M.H. Isolation of a human gene that inhibits HIV-1 infection and is suppressed by the viral Vif protein. Nature 2002, 418, 646-650. [CrossRef] [PubMed] 
73. Zhang, H.; Yang, B.; Pomerantz, R.J.; Zhang, C.; Arunachalam, S.C.; Gao, L. The cytidine deaminase CEM15 induces hypermutation in newly synthesized HIV-1 DNA. Nature 2003, 424, 94-98. [CrossRef] [PubMed]

74. Bishop, K.N.; Holmes, R.K.; Malim, M.H. Antiviral potency of APOBEC proteins does not correlate with cytidine deamination. J. Virol. 2006, 80, 8450-8458. [CrossRef] [PubMed]

75. Bishop, K.N.; Verma, M.; Kim, E.Y.; Wolinsky, S.M.; Malim, M.H. APOBEC3G inhibits elongation of HIV-1 reverse transcripts. PLoS Pathog. 2008, 4, e1000231. [CrossRef] [PubMed]

76. De Pasquale, M.; Kourteva, Y.; Allos, T.; D'Aquila, R.T. Lower HIV provirus levels are associated with more APOBEC3G protein in blood resting memory $\mathrm{CD}^{+} \mathrm{T}$ lymphocytes of controllers in vivo. PLoS ONE 2013, 8, e76002. [CrossRef]

77. Kourteva, Y.; De Pasquale, M.; Allos, T.; McMunn, C.; D'Aquila, R.T. APOBEC3G expression and hypermutation are inversely associated with human immunodeficiency virus type 1 (HIV-1) burden in vivo. Virology 2012, 430, 1-9. [CrossRef] [PubMed]

78. Vetter, M.L.; D'Aquila, R.T. Cytoplasmic APOBEC3G restricts incoming Vif-positive human immunodeficiency virus type 1 and increases two-long terminal repeat circle formation in activated T-helper-subtype cells. J. Virol. 2009, 83, 8646-8654. [CrossRef] [PubMed]

79. Livak, K.J.; Schmittgen, T.D. Analysis of relative gene expression data using real-time quantitative PCR and the 2(-Delta Delta C(T)) method. Methods 2001, 25, 402-408. [CrossRef] [PubMed]

80. Chiu, Y.L.; Witkowska, H.E.; Hall, S.C.; Santiago, M.; Soros, V.B.; Esnault, C.; Heidmann, T.; Greene, W.C. High-molecular-mass APOBEC3G complexes restrict alu retrotransposition. Proc. Natl. Acad. Sci. USA 2006, 103, 15588-15593. [CrossRef] [PubMed]

81. Opi, S.; Takeuchi, H.; Kao, S.; Khan, M.A.; Miyagi, E.; Goila-Gaur, R.; Iwatani, Y.; Levin, J.G.; Strebel, K. Monomeric APOBEC3G is catalytically active and has antiviral activity. J. Virol. 2006, 80, 4673-4682. [CrossRef] [PubMed]

82. Goila-Gaur, R.; Khan, M.A.; Miyagi, E.; Kao, S.; Opi, S.; Takeuchi, H.; Strebel, K. HIV-1 Vif promotes the formation of high molecular mass APOBEC3G complexes. Virology 2008, 372, 136-146. [CrossRef] [PubMed]

83. Shultz, L.D.; Saito, Y.; Najima, Y.; Tanaka, S.; Ochi, T.; Tomizawa, M.; Doi, T.; Sone, A.; Suzuki, N.; Fujiwara, H.; et al. Generation of functional human T-cell subsets with hla-restricted immune responses in HLA class I expressing NOD/SCID/IL2r gamma(null) humanized mice. Proc. Natl. Acad. Sci. USA 2010, 107, 13022-13027. [CrossRef] [PubMed]

84. Chen, K.; Huang, J.; Zhang, C.; Huang, S.; Nunnari, G.; Wang, F.X.; Tong, X.; Gao, L.; Nikisher, K.; Zhang, H. Alpha interferon potently enhances the anti-human immunodeficiency virus type 1 activity of APOBEC3G in resting primary CD4 T cells. J. Virol. 2006, 80, 7645-7657. [CrossRef] [PubMed]

85. Rose, K.M.; Marin, M.; Kozak, S.L.; Kabat, D. Transcriptional regulation of APOBEC3G, a cytidine deaminase that hypermutates human immunodeficiency virus. J. Biol. Chem. 2004, 279, 41744-41749. [CrossRef] [PubMed]

86. Stopak, K.S.; Chiu, Y.L.; Kropp, J.; Grant, R.M.; Greene, W.C. Distinct patterns of cytokine regulation of APOBEC3G expression and activity in primary lymphocytes, macrophages, and dendritic cells. J. Biol. Chem. 2007, 282, 3539-3546. [CrossRef] [PubMed]

87. Lin, A.; Minden, A.; Martinetto, H.; Claret, F.X.; Lange-Carter, C.; Mercurio, F.; Johnson, G.L.; Karin, M. Identification of a dual specificity kinase that activates the jun kinases and p38-MPK2. Science 1995, 268, 286-290. [CrossRef] [PubMed]

88. Farrow, M.A.; Kim, E.Y.; Wolinsky, S.M.; Sheehy, A.M. NFAT and IRF proteins regulate transcription of the anti-HIV protein, APOBEC3G. J. Biol. Chem. 2011, 286, 2567-2577. [CrossRef] [PubMed]

89. Li, Q.; Estes, J.D.; Schlievert, P.M.; Duan, L.; Brosnahan, A.J.; Southern, P.J.; Reilly, C.S.; Peterson, M.L.; Schultz-Darken, N.; Brunner, K.G.; et al. Glycerol monolaurate prevents mucosal SIV transmission. Nature 2009, 458, 1034-1038. [CrossRef] [PubMed]

90. Guillot-Delost, M.; Le Gouvello, S.; Mesel-Lemoine, M.; Cherai, M.; Baillou, C.; Simon, A.; Levy, Y.; Weiss, L.; Louafi, S.; Chaput, N.; et al. Human CD90 identifies Th17/Tc17 T cell subsets that are depleted in HIV-infected patients. J. Immunol. 2011, 188, 981-991. [CrossRef] [PubMed]

91. Shen, F.; Ruddy, M.J.; Plamondon, P.; Gaffen, S.L. Cytokines link osteoblasts and inflammation: Microarray analysis of interleukin-17- and TNF-alpha-induced genes in bone cells. J. Leukoc. Biol. 2005, 77, 388-399. [CrossRef] [PubMed] 
92. Ruddy, M.J.; Shen, F.; Smith, J.B.; Sharma, A.; Gaffen, S.L. Interleukin-17 regulates expression of the CXC chemokine LIX/CXCL5 in osteoblasts: Implications for inflammation and neutrophil recruitment. J. Leukoc. Biol. 2004, 76, 135-144. [CrossRef] [PubMed]

93. Hirota, K.; Turner, J.E.; Villa, M.; Duarte, J.H.; Demengeot, J.; Steinmetz, O.M.; Stockinger, B. Plasticity of Th17 cells in peyer's patches is responsible for the induction of T cell-dependent IgA responses. Nat. Immunol. 2013, 14, 372-379. [CrossRef] [PubMed]

94. Lindqvist, M.; van Lunzen, J.; Soghoian, D.Z.; Kuhl, B.D.; Ranasinghe, S.; Kranias, G.; Flanders, M.D.; Cutler, S.; Yudanin, N.; Muller, M.I.; et al. Expansion of HIV-specific T follicular helper cells in chronic HIV infection. J. Clin. Investig. 2012, 122, 3271-3280. [CrossRef] [PubMed]

95. Petrovas, C.; Yamamoto, T.; Gerner, M.Y.; Boswell, K.L.; Wloka, K.; Smith, E.C.; Ambrozak, D.R.; Sandler, N.G.; Timmer, K.J.; Sun, X.; et al. CD4 T follicular helper cell dynamics during SIV infection. J. Clin. Investig. 2012, 122, 3281-3294. [CrossRef] [PubMed]

96. Xu, Y.; Weatherall, C.; Bailey, M.; Alcantara, S.; De Rose, R.; Estaquier, J.; Wilson, K.; Suzuki, K.; Corbeil, J.; Cooper, D.A.; et al. Simian immunodeficiency virus infects follicular helper CD4 T cells in lymphoid tissues during pathogenic infection of pigtail macaques. J. Virol. 2013, 87, 3760-3773. [CrossRef] [PubMed]

97. Liu, F.; Fan, X.; Auclair, S.; Ferguson, M.; Sun, J.; Soong, L.; Hou, W.; Redfield, R.R.; Birx, D.L.; Ratto-Kim, S.; et al. Sequential dysfunction and progressive depletion of candida albicans-specific CD4 T cell response in HIV-1 infection. PLoS Pathog. 2016, 12, e1005663. [CrossRef] [PubMed]

98. Neidleman, J.A.; Chen, J.C.; Kohgadai, N.; Muller, J.A.; Laustsen, A.; Thavachelvam, K.; Jang, K.S.; Sturzel, C.M.; Jones, J.J.; Ochsenbauer, C.; et al. Mucosal stromal fibroblasts markedly enhance HIV infection of CD4 ${ }^{+}$T cells. PLoS Pathog. 2017, 13, e1006163. [CrossRef] [PubMed]

(C) 2017 by the authors. Licensee MDPI, Basel, Switzerland. This article is an open access article distributed under the terms and conditions of the Creative Commons Attribution (CC BY) license (http:/ / creativecommons.org/licenses/by/4.0/). 